УДК 549.623.9

https://doi.org/10.33271/crpnmu/66.154

(C) M. Kutsevol ${ }^{1}$

${ }^{1}$ Dnipro University of Technology, Dnipro, Ukraine

\title{
NEW DATA ON HALLOYSITE OF UKRAINE
}

\author{
(C) М.Л. Куцевол ${ }^{1}$ \\ ${ }^{1}$ Національний технічний університет «Дніпровська політехніка», Дніпро, Україна
}

\section{НОВІ ДАНІ ПРО ГАЛУАЗИТ УКРАЇНИ}

Purpose. To study the features of a rare variety of halloysite found in the weathering crust of the Derenyukhinskiy gabbro-peridotite massif (located in the the Middle Pobuzhzhya, Southern Buh River region of Ukraine).

Methodology. The study of samples was performed using several techniques: X-ray diffraction analysis (XRD), thermal analysis, optical microscopy, X-ray fluorescence analysis (XRF) and fluorescence spectroscopy.

Findings. A rare chromium-containing variety of halloysite has been identified in the weathering crust of the Derenyukhinskiy gabbro-peridotite massif. Its remarkable features are blue colour, $\mathrm{Cr}_{2} \mathrm{O}_{3}$ content in the amount of up to $2.47 \%$ and luminescence under ultraviolet radiation. The study of the excitation and emission spectra showed that the maximum luminescence of this variety of halloysite occurs when irradiated with waves with a length of $367 \mathrm{~nm}$, and the emission wavelength corresponds to the region of 390-500 nm, with a maximum at $424 \mathrm{~nm}$. The studied sample was actually a mixture of two mineral species: halloysite $(10 \AA)$ and halloysite $(7 \AA)$ or metahalloysite. Aluminian chromite was identified in association with them, and impurities of kaolinite, clinochlore, quartz and goethite were detected. The formation of the mineral aggregate was due to chemical weathering of primary silicates and oxides, which were part of the rocks of the Derenyukhinskiy massif.

Originality. Halloysite has been identified for the first time in the weathering crust of the Derenyukhinskiy gabbro-peridotite massif (Middle Pobuzhzhya). It was found that chromiumcontaining halloysite exhibits violet luminescence under ultraviolet radiation. The fluorescence spectrum of the mineral also has been studied.

Practical implication. Detection of luminescence of chromium-containing halloysite may be helpful in the use of composite materials made of this mineral, designed to remove chromium from wastewater.

Keywords: Middle Pobuzhzhya, chromium-containing halloysite, luminescence, fluorescence spectroscopy, chemical weathering.

Introduction. The name "halloysite" is used for two mineral species of the kaolinite group: halloysite $(10 \AA)$ and halloysite $(7 \AA)$, which differ in certain parameters of the crystal lattice and the number of water molecules per unit formula [1]. The first mineral has the chemical formula $\mathrm{Al}_{2}\left[\mathrm{Si}_{2} \mathrm{O}_{5}\right](\mathrm{OH})_{4} \times 2 \mathrm{H}_{2} \mathrm{O}$, while the second one is a dehydrated compound having the formula $\mathrm{Al}_{2}\left[\mathrm{Si}_{2} \mathrm{O}_{5}\right](\mathrm{OH})_{4}$ and the synonym "metahalloysite". The peculiarity of their crystal structure is that the packages of tetrahedral and octahedral layers are folded into hollow tubes. Homogeneous mixtures of these minerals commonly occur in nature and the general term "halloysite" is applied to such mixtures. Chemically pure natural halloysite is characterized by 
white colour and has no luminescent properties.

In Ukraine, halloysite is a relatively common mineral whose formation is associated with metasomatic processes and chemical weathering of rocks. It was found by the author in association with alunite and gibbsite at the Nikopol manganese deposit in the contact zone between the manganese oxide ore and the clay rock overlapping it. It was concluded that the minerals were formed due to sulfuric acid weathering [2]. In the Middle Pobuzhzhya region of the Ukrainian shield (Southern Buh River area), halloysite was diagnosed by predecessors in the weathering crust of the Lypovenkivskiy and Kapitanivskiy ultrabasite massifs. It was found in rare aggregates forming thin veinlets and small concretions among ocher and ocher clays, and also as an impurity in green chromium-containing montmorillonite clay, which was located in some parts of the surface of the weathering crust [3].

Lately, halloysite has become of great interest to researchers because, due to its properties, it is used in the manufacture of advanced materials [4, 5]. Studies have shown the suitability of nanocomposite material based on halloysite for purification of wastewater from such a toxic element as chromium [6]. Chemical adsorption of complex $\mathrm{Cr}(\mathrm{VI})$ anions on halloysite nanotubes with its reduction to $\mathrm{Cr}(\mathrm{III})$ has been proven.

Some geological processes also lead to the appearance of halloysite which contains chromium. Cr-bearing montmorillonite and halloysite were described in the veins formed as a result of hydrothermal alteration of ultrabasic rocks of the Crommyonia region (Greece) [7]. Chromium montmorillonite of this area has a light green color and contains $6.2 \mathrm{wt} \% \mathrm{Cr}_{2} \mathrm{O}_{3}$, and chromium halloysite is blue, with average content of $\mathrm{Cr}_{2} \mathrm{O}_{3} 4.3 \mathrm{wt} \%$. The authors of the cited article concluded that $\mathrm{Cr}$ (III) ions should occupy octahedral positions in the crystal structure of both clay minerals. They considered chromium-spinel to be the source of this element wich was leached by acidic hydrothermal solutions.

To date, chromium-containing halloysite has not been described in Ukraine.

The purpose of this study is to examine the features of a rare variety of halloysite found in the weathering crust of the Derenyukhinskiy gabbro-peridotite massif (located in the the Middle Pobuzhzhya, Southern Buh River area of Ukraine).

Brief information about the geology of ultrabasites of the Middle Pobuzhzhya. The Middle Pobuzhzhya is a geological region in the southwestern part of the Ukrainian shield. Archaean intrusions of ultrabasites common in this area are divided into two complexes: Kapitanivskiy (dunite-harzburgite formation) and Derenyukhinskiy (dunite-peridotite-gabbronorite formation) [8]. The massifs belonging to the first complex consist of serpentinized peridotite, dunite and harzburgite. They contain deposits and ore occurrences of chromite ores. The rocks of the second complex include gabbroids (gabbronorite, norite), peridotite, pyroxenite, and sometimes dunite. Zones of sulfidization were observed at the contact of ultrabasites and gabbroids. Mesozoic weathering crust over the massifs of both complexes enclose silicate nickel deposits. The following layers are distinguished in the weathering profile (from bottom to top): disintegrated rocks, hydromica zone, nontronite zone, ironstone and ocher zone. 
Materials and methods. In the quarry of the Southern section of the Derenyukhinskiy nickel deposit, among the loose hydromica-nontronite rocks of the weathering crust, the author of this article discovered a lenticular-shaped mineral aggregate, which differed from the host rock in blue color. Samples were selected for the study, which was conducted using a binocular optical microscope, polarizing optical microscope, X-ray diffraction analysis (XRD), thermal analysis, ultraviolet gemological lamp, X-ray fluorescence analysis (XRF) and fluorescence spectroscopy.

$\mathrm{X}$-ray diffraction analysis was performed in the laboratory of the Institute of Geochemistry, Mineralogy and Ore Formation named after M.P. Semenenko of National Academy of Sciences of Ukraine using an automatic diffractometer DRON3M. A file of standards of the PDF-2 2003 database of the International Center for Diffraction Data (ICDD) was used for the identification of mineral phases, with application of the PCPDFWIN program. The positions of the diffraction maxima on the diffractograms were compared with the reference values for minerals in this database.

Thermal analysis was performed in the laboratory of differential thermal analysis of the Ukrainian State University of Chemical Technology (Dnipro) using the "Derivatograph Q - 1500 D" device.

Energy dispersive X-ray fluorescence analysis was used to study the chemical composition of minerals and their aggregates. It was performed in the Laboratory of Analytical Research of Dnipro University of Technology using an X-ray fluorescence spectrometer "ElvaX plus", which allows to determine chemical elements from $\mathrm{Na}$ to U. Characteristic X-rays generated by the atoms of the test sample during the experiment were recorded with a detector and analyzed according to the calibration characteristics of the device.

The luminescence of the sample was studied using a spectrofluorimeter "Fluorolog FL 3-22". The device comprises two spectrometers, one of which measures the excitation spectrum and the other measures the photoluminescence spectrum. In the study, light from the source passed through the first spectrometer and was directed through the powdered sample. The luminescence from the sample was filtered using an emission spectrometer, from which the signal was fed to the detector. Initially, waves of different lengths were sent to the sample and the excitation spectrum was recorded. In the second stage of the analysis, only rays with a certain wavelength were used and the luminescence spectrum was recorded (a change in the fluorescence intensity depending on the wavelength emitted by the sample). Photoluminescence spectra were studied at the "Fluorescence Spectroscopy" Center for Collective Use of Instruments of the National Academy of Sciences of Ukraine (the Department of Lanthanide Chemistry of the Physicochemical Institute named after A.V. Bogatsky, NAS of Ukraine, Odessa).

Results. The mineral aggregate of halloysite is dense, cryptocrystalline, its hardness is 1-2. The colour is uneven, mostly light blue, with small white areas, the streak is white, lustre varies from waxy to earthy. There are tortuous cracks (Fig. 1) in some places, characteristic of metacolloid formations, as well as thin veinlets composed of brown goethite aggregate. Microscopic isometric black inclusions of 
aluminian chromite and scaly colorless grains of clinochlore with vitreous lustre were observed in the blue mass when samples were studied using a binocular optical microscope.

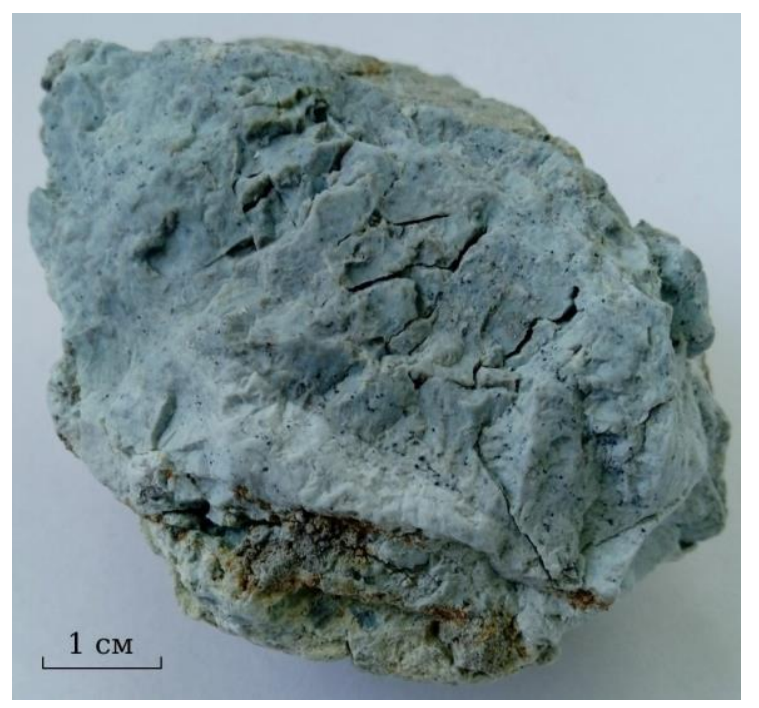

Fig. 1. A sample of halloysite from the weathering crust of the Derenyukhinskiy massif.

The shape of the differential thermal analysis graph of the sample of the blue mineral aggregate is typical for hydrated halloysite. It recorded two endothermic effects and one exothermic one, with a maximum at a temperature of $970{ }^{\circ} \mathrm{C}$. The first endothermic effect in the temperature range of $100-200^{\circ} \mathrm{C}$ is associated, according to [1], with the release of adsorbed water. The second one, with a maximum at $550{ }^{\circ} \mathrm{C}$, has a larger amplitude and is caused by the release of water, which was part of the crystal structure in the form of hydroxyl groups. The exothermic reaction is caused by the crystallization of the amorphous phase, which formed when the sample was heated. The graph of thermogravimetric analysis recorded a decrease in the mass of the sample in two temperature intervals, which coincide with the temperature of the above-described reactions of dehydration of halloysite and destruction of its crystal lattice.

The results of X-ray diffraction analysis revealed that the main mineral of the aggregate was partially dehydrated halloysite (metahalloysite); hydrated halloysite and a small amount of impurities of kaolinite and clinochlore were also present in the sample. The diffraction maximum of metahalloysite $(\mathrm{d}=0.445 \mathrm{~nm})$ has the highest intensity on the diffractogram (Fig. 2), and other peaks corresponding to the interplanar distances of this mineral are observed: $0.770 \mathrm{~nm}(001), 0.363 \mathrm{~nm}(002)$, 0.257 and $0.239 \mathrm{~nm}$. Reflexes 001 and 002 are expanded, which indicates a disorder of its crystal structure. The maxima of $d=1.007 \mathrm{~nm}(001)$ and $0.237 \mathrm{~nm}$ of hydrated halloysite were also recorded. Kaolinite's reflexes correspond to $\mathrm{d}=0.430 \mathrm{~nm}$, $0.356,0.249$ and $0.233 \mathrm{~nm}$. Weak maxima corresponding to interplanar distances of $1,410 \mathrm{~nm}, 7,080 \mathrm{~nm}$ and some others match clinochlore. 


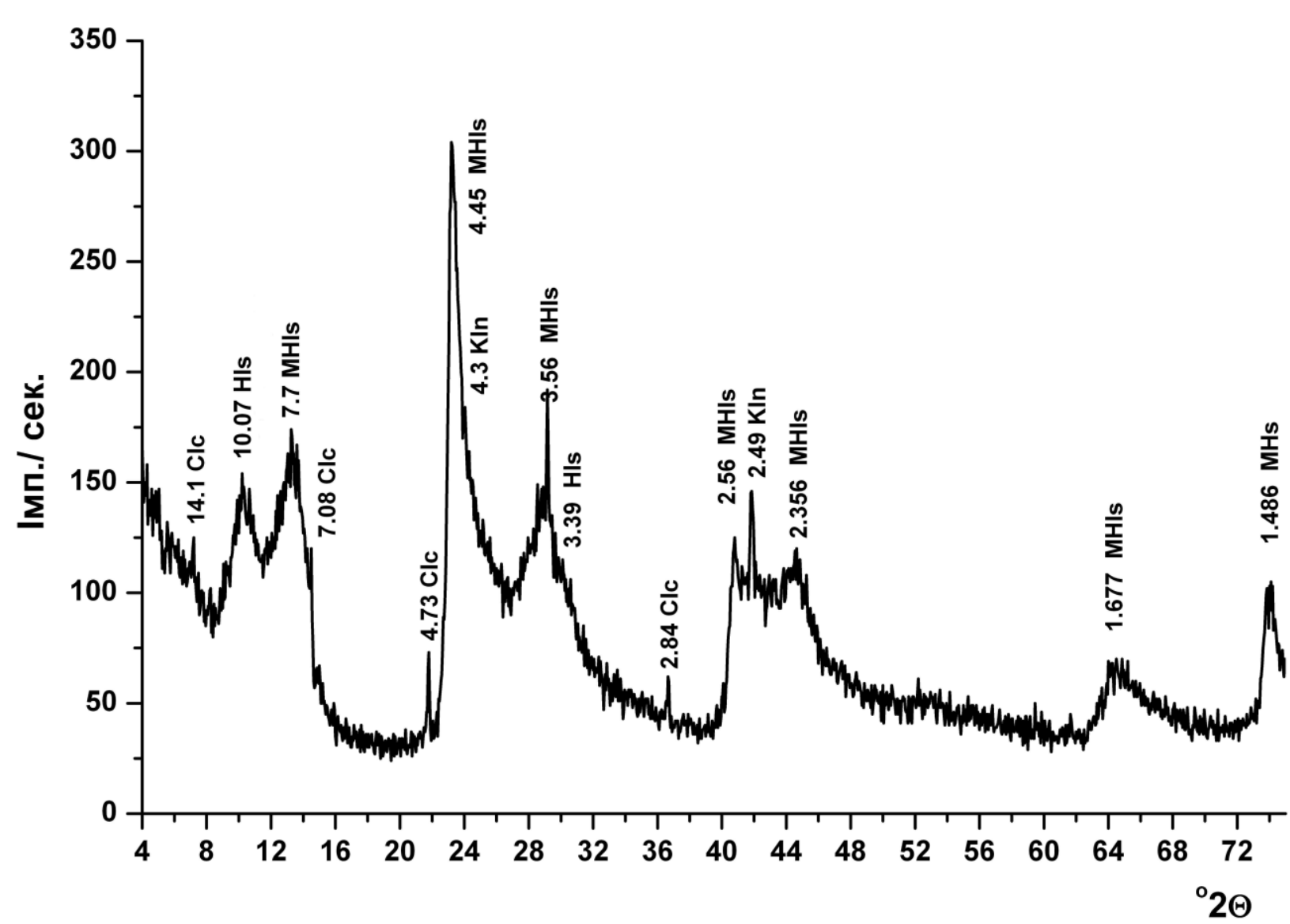

Fig. 2. The diffractogram of the halloysite sample (Сока radiation).

The names of mineral phases and values of interplanar distances in angstroms are shown near diffraction maxima (MHls - metahalloysite, Hls - halloysite, Kln kaolinite, Clc - clinochlore).

Halloysite samples show fluorescence of violet colour under long-wave ultraviolet radiation (Fig. 3).

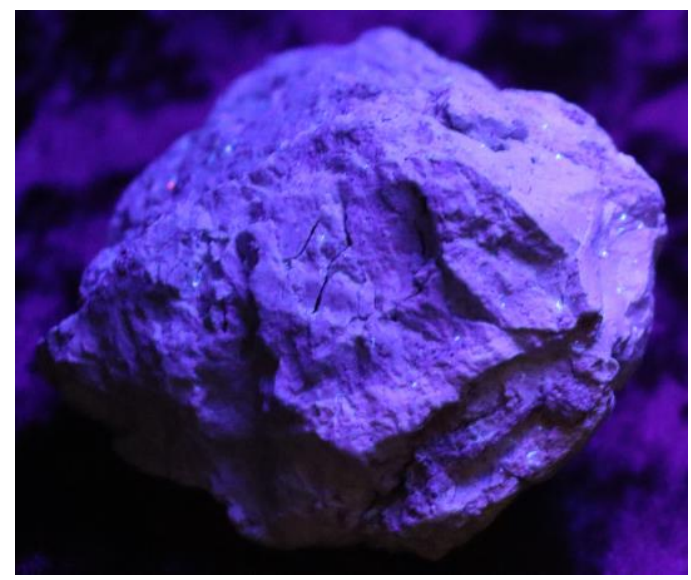

Fig. 3. Fluorescence of halloysite sample from the weathering crust of the Derenyukhinskiy massif.

The excitation and luminescence spectra were obtained using a spectrofluorimeter. The excitation spectrum consists of a wide band in the region of 
$320-400 \mathrm{~nm}$ with a maximum at $367 \mathrm{~nm}$. When the sample is irradiated with waves of this length, luminescence is registered in the form of a wide (half-width is $84 \mathrm{~nm}$ ) band in the region of 390-500 nm with a maximum at $424 \mathrm{~nm}$ and a shoulder at $433 \mathrm{~nm}$ (Fig. $4)$.

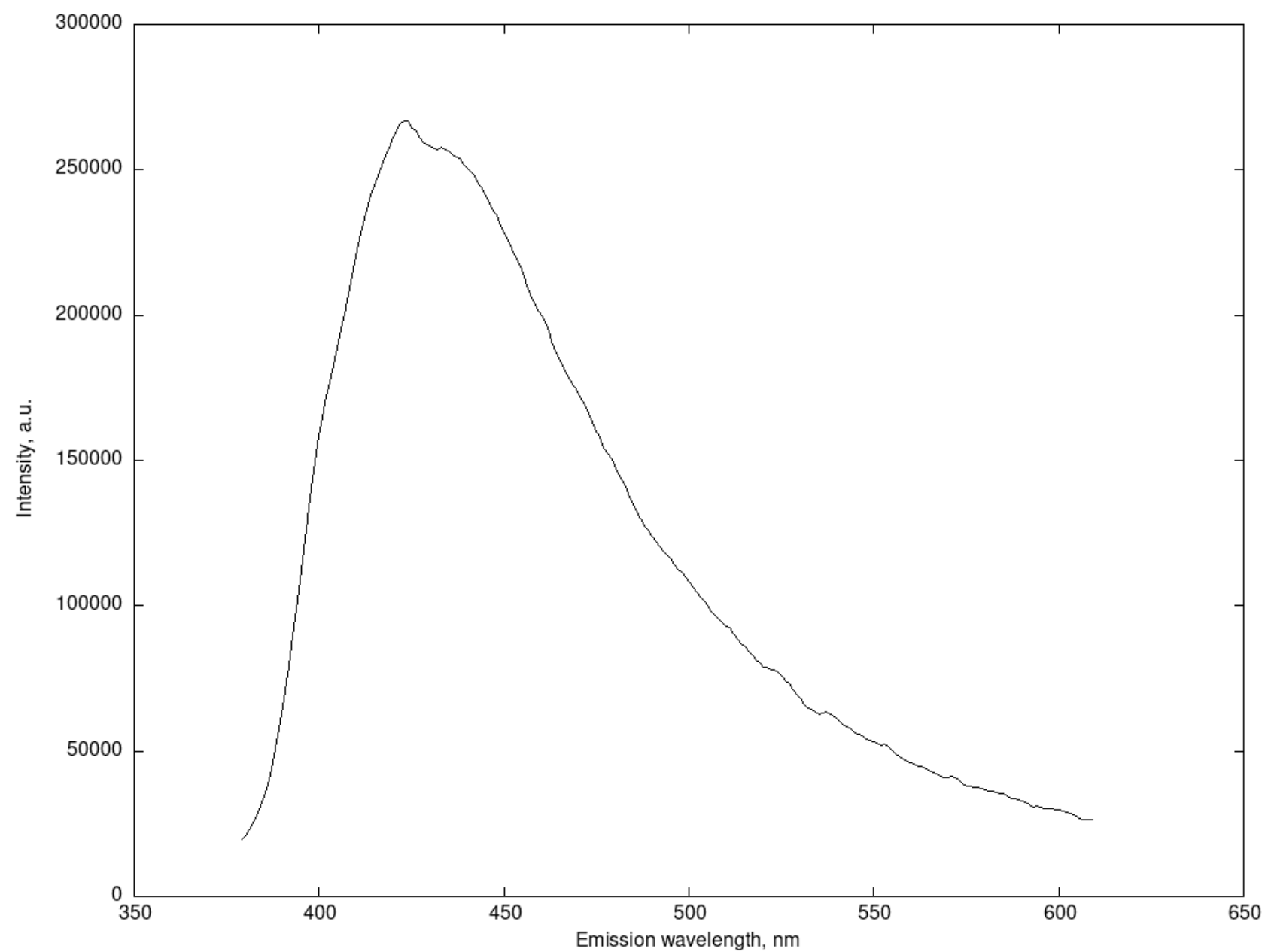

Fig. 4. The fluorescence spectrum of the studied halloysite.

X-ray fluorescence analysis (XRF) of clean halloysite samples showed that, in addition to the main chemical elements (silicon and aluminum), the clay mineral contains impurities of chromium and some other metals. The content of $\mathrm{Cr}_{2} \mathrm{O}_{3}$ in the samples was $1.87 \ldots 2.47 \%, \mathrm{Fe}_{2} \mathrm{O}_{3}-1.49 \ldots 2.23 \%, \mathrm{MgO}-$ up to $1.89 \%, \mathrm{CaO}-$ $0.40 \ldots 1.72 \%, \mathrm{TiO}_{2}-0.42 \ldots 0.60 \%$.

When studying the samples in thin sections, it was observed that there were areas of halloysite with a very weak double refraction (0.002), which gradually turned into zones with higher double refraction (0.007) and undulose extinction (Fig. 5). There were angular-rounded black crystals of opaque mineral (aluminian chromite) and flakes of biotite replaced by clinochlore in the aggregate. 

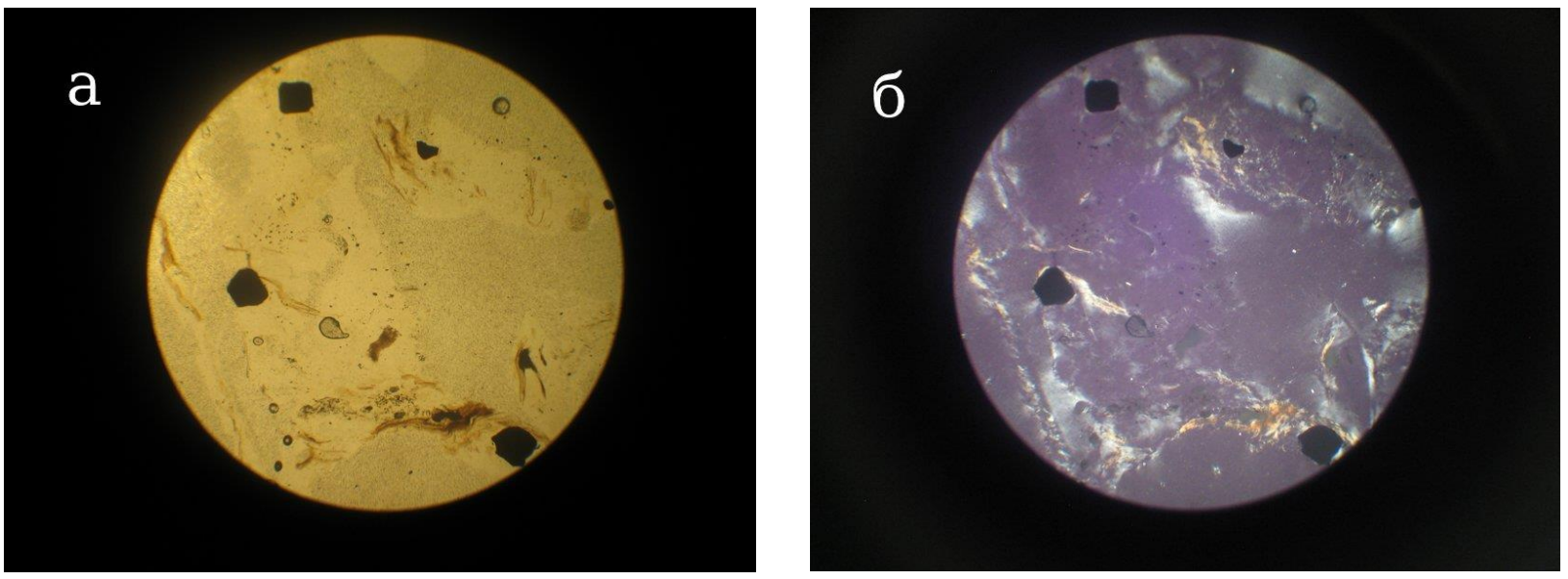

Fig. 5. The aggregate in thin section $(\mathrm{a}-$ plane polarized light, $\mathrm{b}$ - crosspolarized light). The diameter of the field of view is $2 \mathrm{~mm}$.

Aluminian chromite is contained in the aggregate of halloysite in the amount of $1-2 \%$. Its grain sizes are $0.01-0.25 \mathrm{~mm}$ in diameter, colour is black, lustre is submetallic. The mineral was diagnosed with the help of X-ray diffraction and X-ray fluorescence techniques. For these studies, the clay specimen was soaked in water, and a sample enriched with ore mineral was taken from the suspension. XRF analysis revealed $\mathrm{Cr}_{2} \mathrm{O}_{3}$ content of $50.56 \%$ in it.

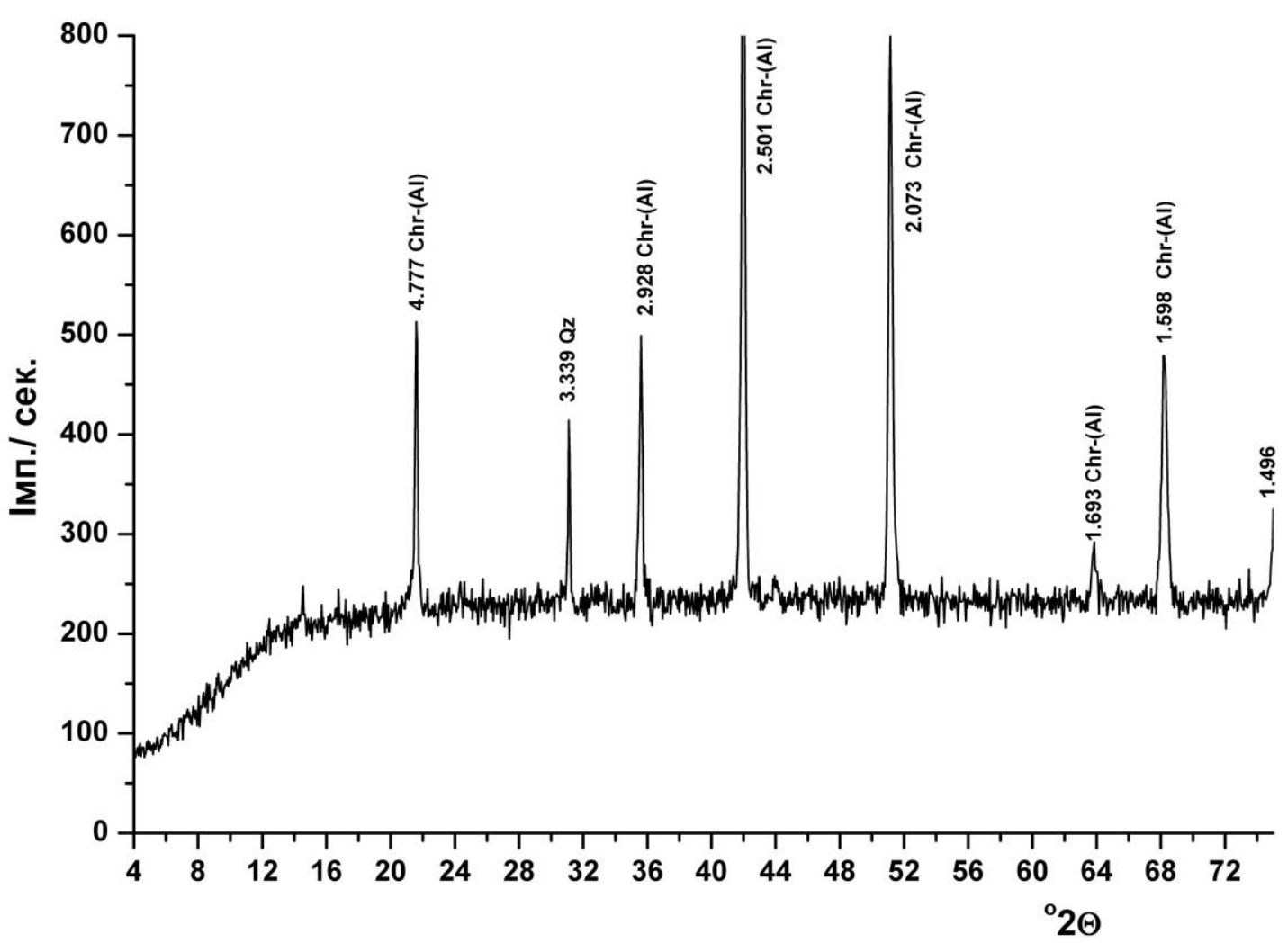

Fig. 6. The diffractogram of the sample enriched in chromite (Сока radiation). Chr-(Al) - aluminian chromite, Qz - quartz. 
On the diffractogram obtained studying the same sample (Fig. 6), all diagnostic reflexes of aluminian chromite were recorded. In addition to them only the strongest of the X-ray maximum corresponding to quartz was registered, which indicates that the latter mineral is present in a very small quantity.

Discussion. It is known that the luminescence of minerals is caused by luminophores (certain ions, complex anionic groups or defects in the crystal structure) $[9,10]$. They include, in particular, the Cr(III) ion, which is a chromophore as well and causes the colour in minerals. Presumably, the blue colour and violet fluorescence of the studied halloysite are due to the presence of trivalent chromium ions in it. The latter could occupy sites in the crystal lattice of the mineral or be chemically adsorbed on the surface of its nanoparticles. It should be noted that kaolinite, which is the main associated mineral of the studied halloysite, sometimes has luminescent properties, but they show only when the mineral is irradiated with cathode rays (fast electron flux) [10].

When considering the genesis of halloysite of the weathering crust of the Derenyukhinskiy massif, it should be taken into account that the composition of hypergenetic products depends on both the initial mineral associations and the physicochemical conditions of the weathering process. For example, according to [11], the leading role in the formation of clay minerals is played by $\mathrm{pH}$ : kaolinite and halloysite form in an acidic environment, montmorillonite - in an alkaline one. Chrome spinels are resistant to chemical weathering. They accumulate in the upper layer of the weathering crust and can then undergo mechanical scattering. However, it was noted that the chromium content in chromites from the weathering crust of the Middle Pobuzhzhya (34-28\%) is lower compared to primary ores (39-43.5\%) due to partial oxidation of minerals and chromium replacement by iron [12]. Therefore, chromium which is responsible for the colour and luminescence of the studied halloysite could come into solutions during chemical weathering of chromite.

It can be assumed that in the area where the halloysite aggregate was formed, the composition of the original rock and weathering conditions differed from those that existed nearby. As noted above, sulfidization was observed at the contact of ultrabasites and gabbroids in the massifs belonging to the Derenyukhinskiy complex. It is probable that, due to chemical weathering of sulfides which occurred above, quite acidic solutions ( $\mathrm{pH} 3-5)$ were created. Due to the partial chemical change of accessory aluminian chromite, trivalent chromium was oxidized to the hexavalent state and entered the solutions. There was also a gradual dissolution of the primary silicates with almost simultaneous formation of new mineral in the form of $\mathrm{Cr}$-containing halloysite. Over time, the colloidal substance lost water which was accompanied by cracking and halloysite $(10 \AA)$ turned into halloysite $(7 \AA)$.

Conclusions. The results of the study supplement the preexisting information on the mineralogy and geology of the Middle Pobuzhzhya region. For the first time, halloysite was identified in the weathering crust of the Derenyukhinskiy gabbroperidotite massif. It is a mixture of two mineral species: halloysite $(10 \AA)$ - hydrated halloysite and halloysite $(7 \AA)$ - metahalloysite. Specific features of the minerals are blue colour and the content of $\mathrm{Cr}_{2} \mathrm{O}_{3}$ in the amount of up to $2.47 \%$. 
It was found that Cr-containing halloysite exhibits violet luminescence under long-wave ultraviolet radiation. The excitation and emission spectra of the mineral mixture have been studied.

Aluminian chromite was diagnosed in association with halloysite; impurities of kaolinite, clinochlore, quartz and goethite were also detected. The formation of the studied mineral aggregate was due to the chemical weathering of primary silicates and oxides which were part of the rocks of the Derenyukhinskiy massif.

Discovery of luminescence of Cr-containing halloysite under ultraviolet radiation may be helpful when using composite materials made of this mineral designed to purify wastewater from chromium.

Acknowledgments. The author expresses her sincere gratitude to S.S. Smola and S.V. Shevchenko for their assistance in the study of halloysite fluorescence.

\section{References}

1. Joussein, E. (2016). Geology and Mineralogy of Nanosized Tubular Halloysite. In Developments in Clay Science (pp. 12-48).

https://doi.org/10.1016/B978-0-08-100293-3.00002-9

2. Куцевол, М.Л., \& Куцевол, Л.И. (2015). Алунитсодержащие минеральные ассоциации рудного горизонта Никопольского марганцевого месторождения и их генетическое значение. Геологія та рудоносність Украӥни, 1(1), 43-50.

http://dx.doi.org/10.15421/121506

3. Лебедев, Ю.С. (1965). Минералогия и генезис коры выветривания гипербазитов Среднего Побужсья. Наук. Думка.

4. Gray-Wannell, N., Holliman, P. J., Greenwell, H. C., Delbos, E., \& Hillier, S. (2020). Adsorption of phosphate by halloysite (7 $\AA$ ) nanotubes (HNTs). Clay Minerals, 55(2), 184-193.

https://doi.org/10.1180/clm.2020.24

5. Abdullayev, E., \& Lvov, Y. (2016). Chapter 22 - Halloysite for controllable loading and release. Developments in clay science, Volume 7. 554-605. https://doi.org/10.1016/B978-0-08-100293-3.00022-4

6. Deb, A.K., Biswas, B., Naidu, R., \& Rahman, M.M. (2022). Mechanistic insights of hexavalent chromium remediation by halloysite-supported copper nanoclusters. Journal of Hazardous Materials, Volume 421.

https://doi.org/10.1016/j.jhahzmat.2021.126812

7. Mitsis, I., Godelitsas, A., Göttlicher, J., Steininger, R., Gamaletsos, P.N., Perraki, M., AbadOrtega, M.M., \& Stamatakis, M. (2018). Chromium-bearing clays in altered ophiolitic rocks from Crommyonia (Soussaki) volcanic area, Attica, Greece. Applied clay science, Volume 162, 362-374.

https://doi.org/10.1016/j.clay.2018.06.016

8. Єсипчук, К.Є. \& Веліканов, В.Я. (ред.) (2004). Державна геологічна карта Украйни масштабу 1:200 000. Аркуш М-36-ХХХІ (Первомайськ). Пояснювальна записка. Держ. комітет природних ресурсів.

9. Марфунин, А.С. (1975). Спектроскопия, люминесценция и радиационные ијентры в минералах. Недра.

10. MacRae, C.M., \& Wilson, N.S. (2008). Luminescence Database I - Minerals and Materials. Microscopy and Microanalysis, 14, 184-204. https://doi.org/10.1017/S143192760808029X

11. Шварцев, С.Л. (1980). Стадийность выветривания как следствие изменения гидрохимических условий среды. Проблемы теории образования коры выветривания и экзогенные месторождения. Наука, 161-168. 
12. Перков, Е.С., \& Поповченко, С.Е. (2012). Минералого-геохимические особенности зональности коры выветривания Восточно-Липовеньковского массива (Среднее Побужье Украинского щита). Науковий вісник НГУ, 3, 18-25.

\begin{abstract}
АНОТАЦІЯ
Мета. Дослідження особливостей рідкісного різновиду галуазиту, який був виявлений у корі вивітрювання Деренюзького габро-перидотитового масиву (Середнє Побужжя, район р. Південний Буг, Україна).
\end{abstract}

Методика дослідження. Вивчення зразків проводилося за допомогою комплексу лабораторних методів: рентгенівського дифракційного аналізу, термічного аналізу, оптичної мікроскопії, рентгенофлуоресцентного аналізу і флуоресцентної спектроскопії.

Результати дослідження. У корі вивітрювання Деренюзького габро-перидотитового масиву встановлено рідкісний хромвмісний різновид галуазиту. Його особливостями є блакитне забарвлення, вміст $\mathrm{Cr}_{2} \mathrm{O}_{3}$ у кількості до $2,47 \%$ і люмінесценція під дією ультрафіолетового випромінювання. Дослідження спектрів збудження i флуоресценції показало, що максимальне світіння галуазиту відбувається при опромінюванні хвилями 3 довжиною 367 нм, а довжина хвиль емісії відповідає області 390-500 нм, 3 максимумом при 424 нм.

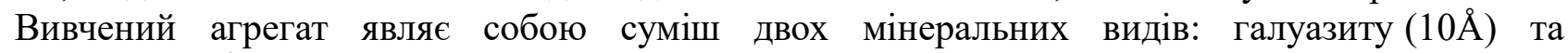
галуазиту (7А̊) (метагалуазиту). В асоціації з ними діагностований алюмохроміт, виявлені домішки каолініту, клінохлору, кварцу та гетиту. Формування мінерального агрегату відбулося внаслідок хімічного вивітрювання первинних силікатів і оксидів, що входили до складу гірських порід Деренюзького масиву.

Наукова новизна. Вперше виявленого галуазит у корі вивітрювання Деренюзького габроперидотитового масиву (Середнє Побужжя). Встановлено, що хромвмісний галуазит проявляє під дією ультрафіолетового випромінювання люмінесценцію фіолетового кольору. Досліджено спектр флуоресценції мінералів.

Практичне значення. Виявлення люмінесценції хромвмісного галуазиту може бути корисним при використанні композитних матеріалів 3 цього мінералу, призначених для очищення стічних вод від хрому.

Ключові слова: Середнє Побужжя, хромвмісний галуазит, люмінесценція, флуоресцентна спектроскопія, хімічне вивітрювання.

\begin{abstract}
АННОТАЦИЯ
Цель. Исследование особенностей редкой разновидности галлуазита, который был обнаружен в коре выветривания Деренюхского габбро-перидотитового массива (Среднее Побужье, район р. Южный Буг, Украина).
\end{abstract}

Методика исследования. Изучение образцов проводилось с помощью комплекса лабораторных методов: рентгеновского дифракционного анализа, термического анализа, оптической микроскопии, рентгенофлуоресцентного анализа и флуоресцентной спектроскопии.

Результаты исследования. В коре выветривания Деренюхского габбро-перидотитового массива диагностирована редкая хромсодержащая разновидность галлуазита. Его особенностями являются голубая окраска, содержание $\mathrm{Cr}_{2} \mathrm{O}_{3}$ в количестве до 2,47\% и люминесценция под действием ультрафиолетового излучения. Исследование спектров 
возбуждения и флуоресценции показало, что максимальное свечение галлуазита происходит при облучении волнами с длиной 367 нм, а длина волн эмиссии соответствует области 390-500 нм, с максимумом при 424 нм. Изученный агрегат представляет собой смесь двух минеральных видов: галлуазита $(10 \AA)$ и галлуазита (7尺) (метагаллуазита). В ассоциации с ними диагностирован алюмохромит, обнаружены примеси каолинита, клинохлора, кварца и гетита. Формирование минерального агрегата произошло вследствие химического выветривания первичных силикатов и оксидов, входивших в состав горных пород Деренюхского массива.

Научная новизна. Впервые определен галлуазит в коре выветривания Деренюхского габброперидотитового массива (Среднее Побужье). Установлено, что хромсодержащий галлуазит проявляет под действием ультрафиолетового излучения люминесценцию фиолетового цвета. Изучен спектр флуоресценции минералов.

Практическое значение. Обнаружение люминесценции хромсодержащегого галлуазита может быть полезным при использовании композитных материалов из этого минерала, предназначенных для очистки сточных вод от хрома.

Ключевые слова: Среднее Побужье, хромсодержащий галлуазит, люминесиенция, флуоресцентная спектроскопия, химическое выветривание. 